\title{
Dietary plasticity and the importance of salmon to brown bear (Ursus arctos) body size and condition in a low Arctic ecosystem
}

\author{
Lindsey S. Mangipane ${ }^{1}$ (I) $\cdot$ Diana J. R. Lafferty ${ }^{2} \cdot K^{\prime}$ le Joly ${ }^{3} \cdot$ Mathew S. Sorum ${ }^{3} \cdot$ Matthew D. Cameron $^{3}$. \\ Jerrold L. Belant ${ }^{4}$. Grant V. Hilderbrand ${ }^{5}$. David D. Gustine ${ }^{6}$
}

Received: 16 July 2019 / Revised: 26 May 2020 / Accepted: 29 May 2020 / Published online: 2 June 2020

(C) The Author(s) 2020

\begin{abstract}
Ecological flexibility within animal populations can allow for variation in resource use and foraging decisions. We estimated brown bear (Ursus arctos) diet composition in Gates of the Arctic National Park and Preserve, Alaska from 2013 to 2015 to evaluate how variation in foraging behavior influences body condition and size. We used stable carbon $\left(\delta^{13} \mathrm{C}\right)$ and nitrogen $\left(\delta^{15} \mathrm{~N}\right)$ isotope analyses of sectioned brown bear hair samples to evaluate assimilated diet. We then developed a set of a priori linear models to evaluate differences in the diet composition of brown bears $(n=80)$ in relation to body fat $(\%)$ and mass. The proportion of meat (salmon [Oncorhynchus keta] and terrestrial meat combined) in the diet from July through late September varied between male and female bears, with males $(\bar{x}=62 \%, \mathrm{SD}=30)$ assimilating significantly more meat than females $(\bar{x}=40 \%, \mathrm{SD}=29)$. Most of the meat consumed came from marine-derived resources for males $(53 \%$ of the total diet or $86 \%$ of the meat) and females ( $31 \%$ of the total diet or $77 \%$ of the meat). As we found the range of observed diets was unrelated to physiological outcomes (i.e., percentage body fat), we suggest that ecological flexibility within populations may provide an adaptive advantage by allowing individuals to reduce competition with conspecifics by foraging on alternate food resources. Identifying variable foraging behaviors within a population can allow for a better understanding of complex behaviors and, ultimately, lead to more informed management decisions related to habitat use, development, and harvest.
\end{abstract}

Keywords Niche variation $\cdot$ Ecological plasticity $\cdot$ Brown bear $\cdot$ Diet $\cdot$ Stable isotope $\cdot$ Ursus arctos

Lindsey S. Mangipane

lindsey.a.stutzman@gmail.com

$1 \quad$ U.S. Fish and Wildlife Service, Marine Mammals Management, Anchorage, AK 99503, USA

2 Wildlife Ecology and Conservation Science Lab, Department of Biology, Northern Michigan University, Marquette, MI 49855, USA

3 National Park Service, Gates of the Arctic National Park and Preserve, Fairbanks, AK 99709, USA

4 Global Wildlife Conservation Center, State University of New York College of Environmental Science and Forestry, Syracuse, NY 13210, USA

5 National Park Service, Alaska Regional Office, Anchorage, AK 99501, USA

6 National Park Service, Grand Teton National Park, Moose, WY 83012, USA

\section{Introduction}

Ecological flexibility within animal populations can facilitate diverse behaviors among individuals (Gordon 1991), including variation in resource use and foraging decisions (Bolnick et al. 2003; Svanback and Bolnick 2007). The niche variation hypothesis (NVH; Van Valen 1965) posits that populations with greater niche breadth should display higher levels of among-individual phenotypic and behavioral variation and that behaviorally flexible individuals should have an adaptive advantage. Variation in resource use within a population can allow individuals to meet their energetic needs by exploiting underutilized resources, thereby reducing competition among conspecifics while maintaining a similar level of fitness (Bolnick et al. 2007). Foraging plasticity within a species has been well documented (Bolnick et al. 2003; Araújo et al. 2011; Edwards et al. 2011; Lafferty et al. 2015; Mangipane et al. 2018) and demonstrates how individuals within a population can range from generalist to highly specialized. 
Brown bears (Ursus arctos) are generalist omnivores (Hilderbrand et al. 1996) that persist in diverse habitats (Servheen et al. 1999; Belant et al. 2010; Hilderbrand et al. 2018a) with a variety of available food resources. Under varying environmental conditions across the species' range, brown bear populations have diets that range from those dominated by vegetation (McLellan et al. 1995) to diets that are high in animal protein, such as salmon (Oncorhynchus spp., Hilderbrand et al. 1999) or ungulates (Persson et al. 2001). Within populations, brown bear can also display variable foraging strategies with diets that range from highly mixed (i.e., meat and vegetation) to exceedingly specialized (Lafferty et al. 2015; Costello et al. 2016; Mangipane et al. 2018). Despite variation in diet, individuals within a given population can achieve similar body fat levels (Mangipane et al. 2018). The ability to achieve similar physiological outcomes (i.e., body condition) regardless of diet demonstrates the ability for brown bears to display high levels of behavioral plasticity (Van Daele et al. 2012) as seen through foraging behavior.

Differences in foraging strategies among individuals within a population may be based on body size and daily energy requirements (Robbins et al. 2007). Studies of captive brown bears suggest that mixed diets of $24 \pm 5 \%$ meat and $76 \pm 5 \%$ fruit are the most biochemically efficient for body mass and fat gain in small-bodied bears (Felicetti et al. 2003; Robbins et al. 2007). However, larger-bodied bears have higher energy requirements due to their increased size, which makes foraging on spatially dispersed berries less energetically efficient (Welch et al. 1997). Therefore, large bears often default to an energy-maximizing strategy in which they consume large amounts of highly nutritious meat (Hilderbrand et al. 1999; Costello et al. 2016; Mangipane et al. 2018). In addition to the nutritional benefits small-bodied bears receive from foraging on biochemically optimal mixed diets, they may also benefit by reducing competition and the associated risks posed by larger individuals. For example, female brown bears in southeast Alaska consumed less salmon than sympatric larger males, presumably to reduce risk of infanticide (Ben-David et al. 2004). Therefore, alternate foraging strategies can provide nutritional benefits as well as benefits related to risk reduction, and these advantages ultimately provide support for brown bear behavior following the NVH (Van Valen 1965; Lafferty et al. 2015; Mangipane et al. 2018).

Our objective was to estimate brown bear diet composition in and around Gates of the Arctic National Park and Preserve in north central Alaska, and to evaluate how variation in foraging behavior is related to body size and condition (i.e., percentage body fat). In line with the NVH, we predicted that all individuals would achieve similar levels of body fat despite variable diets. Additionally, we predicted that due to higher daily energy requirements (Robbins et al.
2007), larger-bodied bears would use an energy-maximizing strategy (Hilderbrand et al. 1999) and consume high levels of meat. Alternatively, if the NVH did not hold and variability in individual diets results in differing body fat percentages, smaller bears could have higher body fat percentages due to their ability to forage closer to a biochemically optimal diet (Welch et al. 1997; Robbins et al. 2007).

\section{Materials and methods}

\section{Study area}

Gates of the Arctic National Park and Preserve is a remote and undeveloped park located in the Brooks Range of northern Alaska (Fig. 1; 68 ${ }^{\circ} \mathrm{N}, 154^{\circ} \mathrm{W}$ ). The $34,287 \mathrm{~km}^{2}$ landscape is characterized by spruce forests (Picea spp.), lowland riparian areas, and high alpine terrain. Average annual temperature is $-5^{\circ} \mathrm{C}$; however, summer temperatures can reach above $20{ }^{\circ} \mathrm{C}$ (Wilson et al. 2014). Snow cover is present in the study area from October through May. Brown bear food resources in Gates of the Arctic are considered to be more limited than in more southerly coastal systems due to a short growing season and low ungulate density (Gasaway et al. 1992). Terrestrial meat resources available to bears include moose (Alces alces), caribou (Rangifer tarandus), Dall's sheep (Ovis dalli), and Arctic ground squirrels (Urocitellus parryii). Berries (Vaccinium spp., Empetrum nigrum, Shepherdia canadensis) and herbaceous vegetation are also available on a seasonal basis. Although not previously thought to be a significant food resource for bears in Gates of the Arctic (Sorum et al. 2019), chum salmon (Oncorhynchus keta) have been found to occur in the system in relatively low abundance from mid-July to early September (Alaska Department of Fish and Game Anadromous Waters Catalog https://www.adfg.alaska.gov/sf/SARR/AWC/Catalog).

\section{Animal capture and sample collection}

In spring (April-June) 2014-2016, we captured brown bears via aerial darting from helicopters (Taylor et al. 1989). Bears were anesthetized with a $10-12 \mathrm{mg} / \mathrm{kg}$ mixture of tiletamine hydrochloride and zolazepam hydrochloride (Telazol; Fort Dodge Laboratories, Inc., Fort Dodge, IA; Taylor et al. 1989). At the time of capture, we determined sex, estimated age based on tooth wear (Hilderbrand et al. 2018b), and weighed individuals using an electronic scale $( \pm 0.5 \mathrm{~kg} ;$ MSI-7200, Measurement Systems International, Seattle, WA). We then used bioelectrical impedance analysis to estimate percentage body fat (Farley and Robbins 1994; Hilderbrand et al. 1998). Individuals with body fat percentages below 3\% $(n=4)$ were likely the result of measurement errors, due to the fact that survival with less than $3 \%$ body 


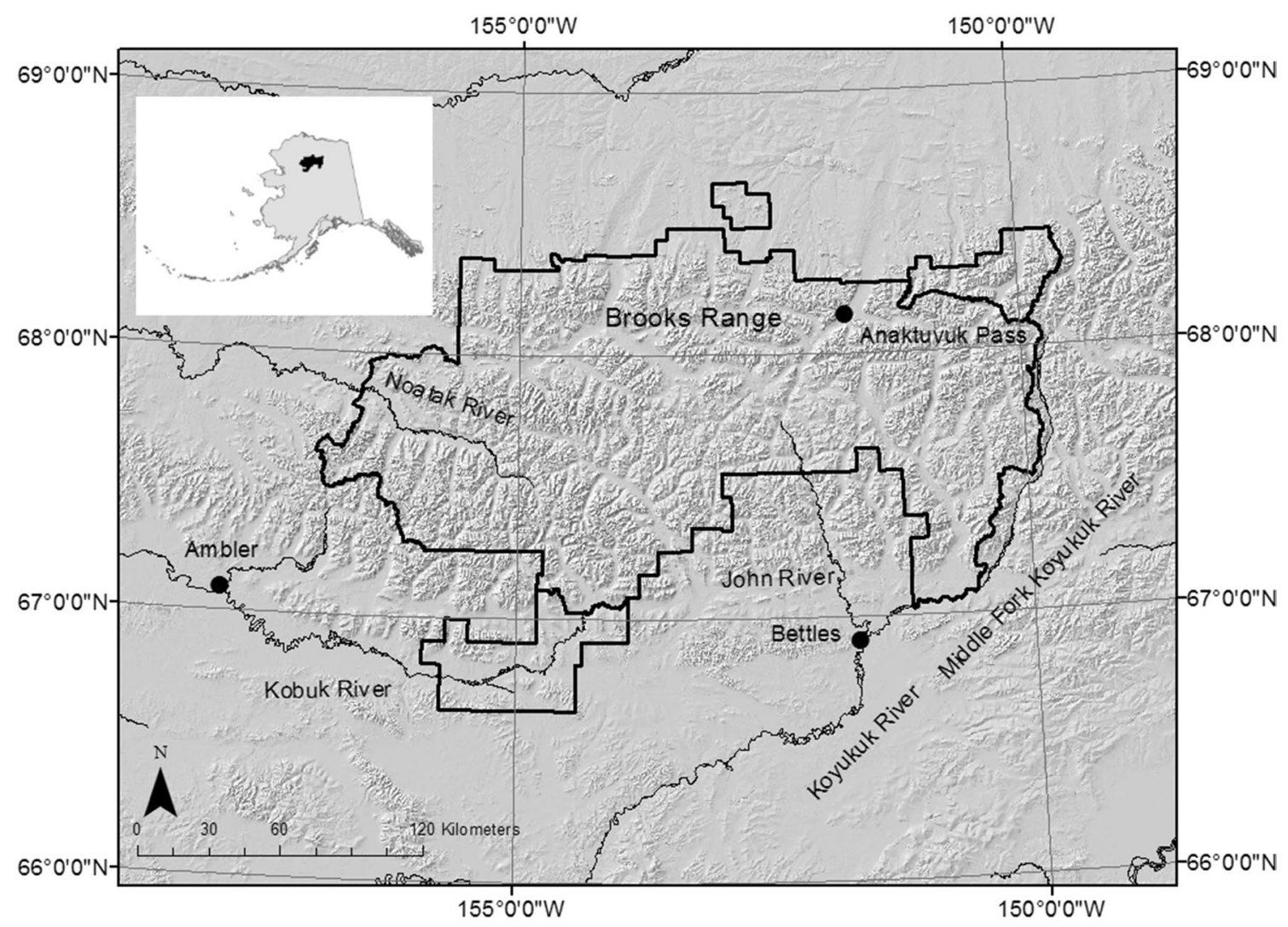

Fig. 1 Gates of the Arctic National Park and Preserve, Alaska, USA

fat is unlikely (J. Teisberg, unpublished data). Therefore, we rounded body fat values up to $3 \%$ for these individuals. Additionally, we removed one individual whose body fat was $50.4 \%$, also likely due to a measurement error. At the time of capture we also collected guard hair samples from between the front shoulders to estimate assimilated diet during the previous fall (Hobson et al. 2000). All hair samples were placed in individually labeled paper envelopes and stored in $\mathrm{a}-20^{\circ} \mathrm{C}$ freezer until analyzed.

\section{Evaluating diet composition}

We used stable carbon $\left(\delta^{13} \mathrm{C}\right)$ and nitrogen $\left(\delta^{15} \mathrm{~N}\right)$ isotope analyses of the hair samples to evaluate assimilated diet, with each bear-year combination identified as an individual sampling unit. Samples were analyzed by the Environment and Natural Resources Institute Stable Isotope Laboratory at the University of Alaska, Anchorage (https://www.uaa. alaska.edu/enri/labs/sils) and followed the methods and reporting outlined by Rogers et al. (2015); Mangipane et al. (2018). To assess the influence of diet on body condition, we used sectioned guard hair samples (from hair collected in spring just after den emergence) to evaluate assimilated diet during the time period when fat gain is most important for bears (i.e., hyperphagia; Cattet et al. 2002). Hair growth in bears occurs from early May through October (Jacoby et al. 1999). Based on a $1.5 \mathrm{~cm} /$ month growth rate (Felicetti et al. 2004) and the estimated assimilation rate for dietary changes to be detectable in hair (isotopic equilibrium is reached at 30-40 days; Oelze 2016), we used the $4 \mathrm{~cm}$ of hair closest to the root for analysis to represent the time period from July through late September of the previous year. Additionally, we adjusted $\delta^{13} \mathrm{C}$ values of hair samples collected in 2015 and 2014 by $-0.022 \%$ and $-0.044 \%$, respectively, to account for the Suess effect, which is the global decrease in $\delta^{13} \mathrm{C}$ content of atmospheric carbon dioxide, as a consequence of humans burning fossil fuels during the past 150 years (Tans et al. 1979; Hopkins and Ferguson 2012). We report isotopic values in delta $(\delta)$ notation such that $\delta^{13} \mathrm{C}$ or $\delta{ }^{15} \mathrm{~N}=\left[\left(\mathrm{R}_{\text {sample }} /\right.\right.$ $\left.\left.\mathrm{R}_{\text {standard }}\right)-1\right] \times 1000$, where $\mathrm{R}_{\text {sample }}$ and $\mathrm{R}_{\text {standard }}$ are the ${ }^{13} \mathrm{C} /{ }^{12} \mathrm{C}$, or ${ }^{15} \mathrm{~N} /{ }^{14} \mathrm{~N}$, ratios of the sample and standard, respectively. The standards are PeeDee Belemnite limestone for carbon and atmospheric $\mathrm{N}_{2}$ for nitrogen.

To determine the proportional contribution of major foods to brown bear diets, we a priori identified three isotopically distinct and important food categories: vegetation, terrestrial meat, and salmon. Although location-specific isotope data for food items in our study area would have been preferred, these data were unavailable at the time of this study. Therefore, we used existing isotopic values reported 
in the literature for similar systems in the region (Table 1). We included generalized plant values and terrestrial meat values for Arctic and sub-Arctic tundra habitats that were previously reported by Mowat and Heard (2006). Additionally, we included values for Chum salmon in Alaska previously reported in a meta-analysis by Johnson and Schindler (2009). Using $\delta^{13} \mathrm{C}$ and $\delta^{15} \mathrm{~N}$ values for each bear as well as $\delta^{13} \mathrm{C}$ and $\delta^{15} \mathrm{~N}$ values, standard deviations, and trophic discrimination values for the major food categories (Mowat and Heard 2006; Johnson and Schindler 2009), we confirmed suitable isotopic mixing space based on visual inspection of the isotopic bi-plot (Fig. 2). We then estimated the proportional contribution of each food category to the diet of brown bears using the Bayesian isotopic mixing model MixSIAR (version 3.1.10; Stock and Semmens 2013). We modeled sex as a fixed effect and included a random effect for individual as well as a term for process error (Moore and Semmens 2008). We fit our model with the Markov Chain Monte Carlo (MCMC) method using uninformative priors to estimate posterior distributions for each food category (Carlin and Siddhartha 1995). We used Gibbs sampling and applied 160,000 chain lengths, a burn-in of 10,000, and thinning of 10 across three chains with JAGS (Plummer 2013). We confirmed model convergence by visually inspecting trace plots and with the Gelman-Rubin diagnostic $(\widehat{R}<1.05$ indicating convergence; Gelman and Rubin 1992), subsequently reporting the mean posterior proportional contributions of each food category ( $\pm 95 \%$ credible intervals) to the diet of individual bears.

\section{Models and model selection}

To avoid including correlated covariates in the same model, we tested continuous covariates using the Pearson productmoment correlation coefficient $(r)$, assuming multicollinearity existed if $|r|>0.70$ (Dormann et al. 2013). We then developed a set of models to evaluate the influence of sex and proportion of total meat in the diet (salmon and terrestrial meat combined) on body mass and body fat. Initially, we included age in the model set; however, it was not retained in the final model because it did not improve model

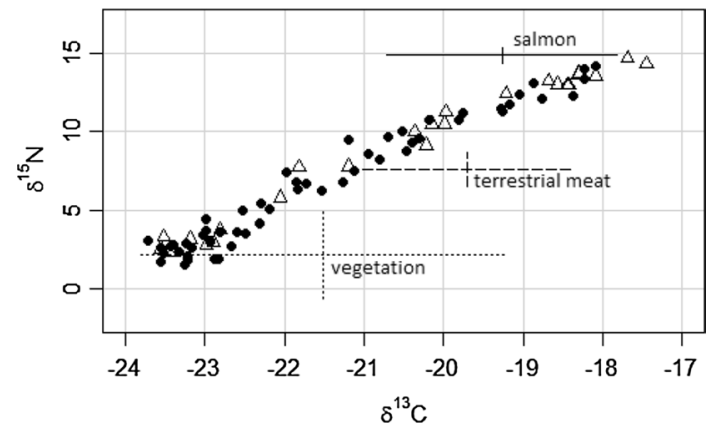

Fig. 2 Mean carbon $\left(\delta^{13} \mathrm{C}\right)$ and nitrogen $\left(\delta^{15} \mathrm{~N}\right)$ stable isotope ratios from 80 ( $n=25$ male, $n=55$ female) sectioned brown bear (Ursus arctos) hair samples and associated food resources, Gates of the Arctic National Park and Preserve, Alaska, USA, July through late September 2013-2015. Discrimination factors were applied to each food category

performance (i.e., did not improve model fit and added an additional variable) and was not significant in any of the models it was included in. Additionally, the random effect of individual did not improve model fit, and due to only having three years of data, we did not include it in the analysis (Bolker et al. 2009). We then chose the highest ranked model based on small-sample Akaike's Information Criterion $\left(\mathrm{AIC}_{\mathrm{c}}\right.$; Burnham and Anderson 2002). Only the most biologically relevant covariates were included in the analysis to avoid over-parameterization. All statistical analyses were conducted using Program R (v3.2.2, www.r-project.org).

\section{Results}

Spring hair samples were collected from 80 ( $n=25$ male, $n=55$ female) independent adult bears during 2014-2016. This included 58 unique individuals, and 22 recapture events. Due to uncertainty of the reproductive status of females during the fall prior to their first spring capture, females were not further categorized based on the presence or absence of dependent young. Carbon $\left(\delta^{13} \mathrm{C}\right)$ values ranged from -23.72 to -17.45 and nitrogen $\left(\delta^{15} \mathrm{~N}\right)$
Table 1 Isotopic ratios of carbon $\left(\delta^{13} \mathrm{C}\right)$ and nitrogen $\left(\delta^{15} \mathrm{~N}\right)$ and associated discrimination factors of potential food sources for brown bears (Ursus arctos), Gates of the Arctic National Park and Preserve, Alaska, USA

\begin{tabular}{lccll}
\hline Source & $\delta^{13} \mathrm{C}(\% \circ) \pm S E$ & $\delta^{15} \mathrm{~N}(\% \circ) \pm S E$ & $\begin{array}{l}\text { Discrimination factor } \\
\delta^{13} \mathrm{C}(\% \circ) \pm S E\end{array}$ & $\begin{array}{l}\text { Discrimina- } \\
\text { tion factor } \delta^{15} \mathrm{~N} \\
(\% \circ) \pm S E\end{array}$ \\
\hline Salmon $^{\mathrm{a}}$ & $-21.27 \pm 0.96$ & $11.10 \pm 0.43$ & $1.99 \pm 1$ & $3.76 \pm 0.45$ \\
Terrestrial Meat $^{\mathrm{b}}$ & $-22.30 \pm 1.00$ & $3.10 \pm 1.005 .18$ & $2.59 \pm 1$ & $4.48 \pm 0.45$ \\
Vegetation $^{\mathrm{c}}$ & $-26.60 \pm 2.00$ & $-2.80 \pm 3.00$ & $5.09 \pm 1$ & $5.01 \pm 0.45$ \\
\hline
\end{tabular}

${ }^{a}$ Meta-analysis of Chum salmon (Oncorhynchus keta) isotopic values reported by Johnson and Schindler (2009)

${ }^{\mathrm{b}}$ Terrestrial meat values from Arctic and sub-Arctic tundra systems reported by Mowat and Heard (2006)

${ }^{\mathrm{c}}$ Generalized plant baseline value reported by Mowat and Heard (2006) 
Table 2 Results of linear models evaluating the proportion of meat assimilated by male and female brown bears (Ursus arctos), Gates of the Arctic National Park and Preserve, Alaska, USA

\begin{tabular}{|c|c|c|c|c|c|}
\hline \multirow[t]{2}{*}{ Response variable } & \multirow[t]{2}{*}{ Parameter } & \multirow[t]{2}{*}{ Estimate } & \multicolumn{2}{|c|}{ 95\% Confidence limits } & \multirow[t]{2}{*}{$p$} \\
\hline & & & Lower & Upper & \\
\hline \multirow[t]{2}{*}{ Proportion assimilated total meat ${ }^{\mathrm{a}}$} & Intercept $^{\mathrm{b}}$ & 0.406 & 0.328 & 0.486 & $<0.0001$ \\
\hline & Male & 0.183 & 0.042 & 0.325 & 0.0117 \\
\hline \multirow[t]{2}{*}{ Proportion assimilated salmon } & Intercept ${ }^{\mathrm{b}}$ & 0.316 & 0.240 & 0.391 & $<0.0001$ \\
\hline & Male & 0.196 & 0.062 & 0.331 & 0.0047 \\
\hline \multirow[t]{2}{*}{ Proportion assimilated terrestrial meat } & Intercept $^{\mathrm{b}}$ & 0.091 & 0.072 & 0.111 & $<0.0001$ \\
\hline & Male & -0.013 & -0.048 & 0.021 & 0.4450 \\
\hline
\end{tabular}

${ }^{\mathrm{a}}$ Total meat is composed of the combined proportions of terrestrial meat and salmon

${ }^{\mathrm{b}} \mathrm{Female}$ is the reference group

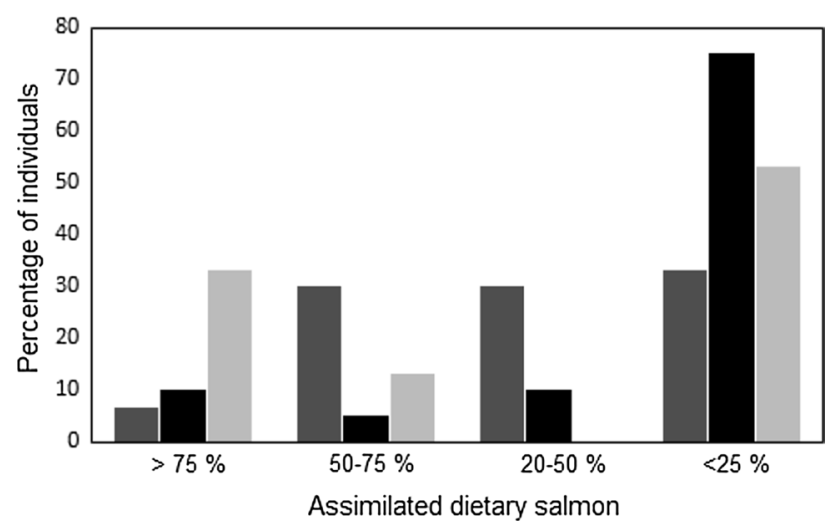

Fig. 3 Assimilated dietary salmon intake of brown bears (Ursus arctos) from July through late September in Gates of the Arctic National Park and Preserve, Alaska, USA. Dark gray, black, and light gray represent 2013, 2014, and 2015 diets, respectively

values in hair samples ranged from 1.52 to 14.68 (Fig. 2). Although we acknowledge some uncertainty due to our isospace geometry (i.e., our sources do not form a prefect equilateral triangle; Phillips and Gregg 2003), our food categories did demonstrate reasonable separation with consumers falling within the mixing area (Fig. 2). Diets varied between male and female bears, with males assimilating significantly higher amounts of meat (salmon and terrestrial meat combined) than females $\left(F_{1,63}=7.143\right.$, $p=0.0117$; Table 2). The contribution of total meat to the diet of brown bears ranged from $3-94 \%(\bar{x}=$ $62 \%, S D=30)$ for males and from 2 to $96 \%(\bar{x}=40 \%$, $S D=29$ ) for females. Conversely, we found that vegetation accounted for $6-97 \%(\bar{x}=41 \%, S D=32$ for males and from 4 to $98 \%(\bar{x}=59 \%, S D=28)$ for females. We found that salmon alone (Fig. 3) comprised 53\% ( $S D=31$, range $=2-93 \%)$ of the diet of males, on average, which was greater $\left(F_{1,63}=8.017, p=0.0047\right)$ than that of females $(\bar{x}=31 \%, S D=27$, range $=1-94 \%)$. Terrestrial meat assimilation was not different between males and females $\left(F_{1,63}=0.001, p=0.4450\right)$ with males ranging from 1 to
Table 3 Candidate linear models used to describe the differences in body fat and body mass of brown bears (Ursus arctos), Gates of the Arctic National Park and Preserve, Alaska, USA

\begin{tabular}{lllrrr}
\hline Response Variable & Rank & Model & $K$ & $\Delta \mathrm{AIC}_{\mathrm{c}}$ & $w$ \\
\hline Body mass (kg) & 1 & $\begin{array}{l}\text { Proportion } \\
\text { meat + sex }\end{array}$ & 4 & 0.00 & 0.99 \\
& & Sex & 3 & 8.77 & $<0.01$ \\
& 2 & Proportion meat & 3 & 20.14 & $<0.01$ \\
& 3 & Null & 2 & 35.89 & $<0.01$ \\
& 4 & 3 & 0.00 & 0.43 \\
Body fat (\%) & 1 & Sex & 2 & 0.59 & 0.32 \\
& 2 & Null & 4 & 2.31 & 0.14 \\
& 3 & Proportion & & & \\
& & meat + sex & 3 & 2.56 & 0.12 \\
\hline
\end{tabular}

$21 \%(\bar{x}=9 \%, S D=7)$ and females from 1 to $29 \%(\bar{x}=$ $9 \%, S D=7)$.

When evaluating the influence of the proportion of assimilated meat in the diet on body mass and body fat, there was correlation between continuous variables $(|r| \leq 0.621)$; however, it was insufficient to preclude any variables from analysis as they were all less than the specified threshold. We collected 65 (49 female, 16 male) spring bear weights. Based on $\mathrm{AIC}_{c}$, the highest ranked model for evaluating the effect of assimilated dietary meat intake on body mass included the proportion of total meat in the diet and sex (Table 3 ). The proportion of meat in the diet was positively correlated with body mass $\left(F_{2,62}=26.69, p=0.0012\right.$, Table 4$)$, with larger bears consuming higher proportions of meat than smaller individuals (Fig. 4). Additionally, males were larger than females $(p<0.0001)$. On average, males weighed $138.0 \mathrm{~kg}$ $(S D=51.1$, range $=64.0-247.5 \mathrm{~kg})$, whereas the average female weighed $88.5 \mathrm{~kg}(S D=15.8$, range $53.5-136.5 \mathrm{~kg})$.

Body fat measurements were collected from 56 individuals (46 female, 10 male) with measurements ranging from $3.0 \%$ to $33.7 \%(\bar{x}=12.1 \%, S D=6.8)$. The highest ranked model for evaluating the influence of diet on body fat only 
Table 4 Results of linear models evaluating the influence of proportion of dietary meat intake on body mass and fat of male and female brown bears (Ursus arctos), Gates of the Arctic National Park and Preserve, Alaska, USA

\begin{tabular}{llrlrl}
\hline $\begin{array}{l}\text { Response } \\
\text { variable }\end{array}$ & Parameter & Estimate & $\begin{array}{l}\text { 95\% confi- } \\
\text { dence limits }\end{array}$ & $p$ \\
\cline { 3 - 4 } & & & Lower & Upper & \\
\hline $\begin{array}{l}\text { Body mass } \\
(\mathrm{kg})\end{array}$ & Intercept $^{\mathrm{a}}$ & 73.480 & 61.76 & 85.20 & $<0.0001$ \\
& Proportion & 38.483 & 15.78 & 61.19 & 0.0012 \\
& meat & & & & \\
& Male & 40.526 & 24.49 & 56.56 & $<0.0001$ \\
Body fat (\%) & $\begin{array}{l}\text { Intercept } \\
\end{array}$ & 11.443 & 9.48 & 13.41 & $<0.0001$ \\
& Male & 3.876 & -0.77 & 8.53 & 0.1000 \\
\hline
\end{tabular}

${ }^{\mathrm{a}}$ The intercept represents female brown bears

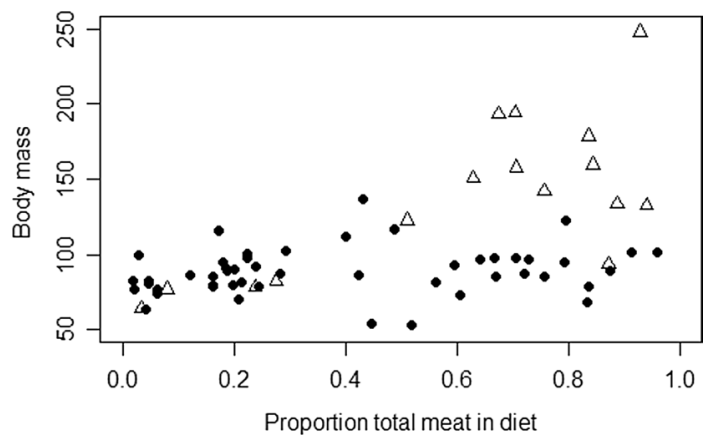

Fig. 4 Relationship between spring body mass (kg) and the proportion of assimilated meat (salmon and terrestrial sources combined) in the diet of brown bears (Ursus arctos) during the hyperphagia period (July through late September 2013-2015) of the year prior to measurement, Gates of the Arctic National Park and Preserve, Alaska, USA. Males are represented by open triangles and females are represented by solid circles

included sex (Table 3). However, we found no relationship between body fat and sex $\left(F_{1,54}=2.79, p=0.1000\right.$, Table 4). Our second highest ranked model was our null hypothesis which was less than $2 \Delta \mathrm{AIC}_{\mathrm{c}}$ from our top ranked model. Given that there were no significant variables in our highest ranked model, the null suggests similar findings to those of our highest ranked model. Therefore, the null was not considered as a competing model.

\section{Discussion}

Brown bears in Gates of the Arctic National Park and Preserve demonstrated variation in foraging behavior consistent with the NVH (Van Valen 1965) and followed dietary patterns scaled to body size as described by Robbins et al. (2007). Bears exhibit sexual size-dimorphism, with males generally having greater mass than females (Lefranc et al. 1987; Swenson et al. 2007; Hilderbrand et al. 2018b). Due to increased nutritional requirements needed for large-bodied males to maintain their body sizes, relatively higher levels of protein consumption are common (Jacoby et al. 1999). Although mixed diets can be beneficial for brown bears (Robbins et al. 2007), larger individuals cannot obtain a biochemically optimal diet as easily as small individuals due to the energetic costs of foraging on dispersed berries (Welch et al. 1997). Increased meat consumption among largerbodied individuals has been documented in other areas of Alaska, including systems with abundant salmon (Mangipane et al. 2018). Although increased body size imposes higher daily energy requirements, the benefits of larger size can provide reproductive (e.g., increased access to mates or greater recruitment; Noyce and Garshelis 1994; Zedrosser et al. 2007; Hilderbrand et al. 2019) and survivorship (e.g., decreased intra-specific predation) benefits. For example, increased body size can provide a positive relationship on the age of first reproduction for male and female bears, female litter size, and weight of offspring (Rode et al. 2014). Therefore, maintaining a large body size may be a desirable trait despite the associated energetic costs.

Variation in diet was not associated with body fat (\%), supporting our hypothesis of behavioral plasticity among individuals. By extension, we suggest that ecological flexibility within populations may provide an adaptive advantage by allowing individuals to reduce competition with conspecifics by foraging on alternate food resources (i.e., the NVH). For example, although brown bears on average assimilated $>40 \%$ salmon in 2013, there was substantial variation in diet among individual (Fig. 3), suggesting that individuals can subsist on variable diets ranging from highly mixed to highly specialized. Although variation in diet can occur due to home-range specific recourse availability (i.e., home ranges that do not have access to anadromous streams), salmon was available to all bears in our study. Therefore, proportional use of salmon may have been more closely tied to an individual's ability to compete for and defend salmon resources. Previous works have found support for the NVH in resource-rich systems (Lafferty et al. 2015; Mangipane et al. 2018); however, this had not been tested in less productive systems. Although brown bears in Gates of the Arctic may not have the resources required to become as large as bears in resource-rich systems (Hilderbrand et al. 2018b), they should be more efficient at gaining fat since they are smaller and therefore have lower daily energy requirements, allowing them to forage more efficiently on dispersed berries (Welch et al. 1997) and closer to a biochemically optimal diet (Robbins et al. 2007). Brown bears in our study did not assimilate the proposed optimal diet (total meat consumed was $62 \%$ for males and $40 \%$ for female versus the proposed optimal of $24 \%$ meat); however, 
they foraged closer to optimal than larger-bodied bears in the interior of Lake Clark National Park and Preserve $(\bar{x}=70 \%$ total meat; Mangipane et al. 2018). Additionally, because the optimal diet (Robbins et al. 2007) was calculated based on dry matter intake, whereas our estimates are based on assimilated diet, these values may not be directly comparable, and therefore, may be closer to optimal than we report. Despite having a more biochemically optimal diet, bears in Gates of the Arctic on average had much lower fat levels than bears in systems with abundant marine resources $(\bar{x}=$ $11.6 \%$ in Gates of the Arctic versus $\bar{x}=18.6 \%$ in Lake Clark, $\bar{x}=15.6 \%$ in Kodiak, and $\bar{x}=12.2 \%$ in Katmai; Hilderbrand et al. 2018a). This suggests that although bears in our study may be small enough to maximize fat gain with a nutritionally mixed diet (Robbins et al. 2007), they may ultimately be unable to do so due to limited resource availability and a shorter active season. In addition to having lower body fat than brown bears in resource-rich systems, bears in Gates of the Arctic are also smaller bodied (Hilderbrand et al. 2018b). Nutrient availability is the most critical factor influencing brown bear body size and population density (Hilderbrand et al. 1999; Mowat and Heard 2006). Therefore, given that systems at higher latitudes are known to be less nutrient rich (Cramer et al. 1999), bears in our study may be unable to attain the levels of body mass and reproduction seen in more productive systems. Unlike female bears in highly productive systems that have been found to grow throughout their life, female bears in Gates of the Arctic reached an asymptote in lean body mass, indicating that the cost of reproduction may be equal to the available nutrient intake possible for brown bears in the system (Hilderbrand et al. 2018a). Therefore, morphological (i.e., body size) and physiological (i.e., percent body fat) differences between bears in our study and those in more productive systems suggest that although bears can be nutritionally flexible in nutrient poor systems, ceilings on overall nutrient acquisition may ultimately limit body condition and size, and thereby reproduction and potentially population density.

Although limited resources may restrict dietary choices in Gates of the Arctic, we found that the assimilated diet of bears included a substantial salmon component. Past studies of brown bears in Arctic regions have documented extensive use of plant based foods (Hechtel 1985; MacHutchon and Wellwood 2003; Edwards et al. 2011), caribou (Gau et al. 2002), aquatic browsers (i.e., moose and beaver [Castor Canadensis]; Edwards et al. 2011)], and small mammals (Hechtel 1985; Edwards et al. 2011). Salmon is an important food resource for many brown bear populations (Hilderbrand et al. 1999; Mangipane et al. 2018), and our results lend additional support for the recent documentation of salmon consumption by bears in this interior, montane system in the low Arctic (Sorum et al. 2019). Gates of the Arctic has relatively low salmon abundance, with limited spatial and temporal distribution (Alaska Department of Fish and Game Anadromous Waters Catalog https://www.adfg.alaska.gov/ sf/SARR/AWC/Catalog). The relatively high proportion of salmon consumed by brown bears (53\% for males and $31 \%$ for females, on average), given their limited availability in the system, demonstrates the high nutritional importance of salmon to these bears, and suggests that salmon is a preferred food when available in the fall. Therefore, some brown bears may be opting to use an energy-maximizing strategy (i.e., consuming high amounts of easily attainable, nutrient dense salmon; Hilderbrand et al. 1999) over a biochemically optimal diet that relies on widely dispersed berries (Robbins et al. 2007). Given these results, emphasis should be given to the importance of science-based salmon management in the system, and the potential impacts reduced salmon runs could have on brown bears in this nutritionally limited system should be evaluated (Hilderbrand et al. 2004).

Our results suggest that the diets of bears in Gates of the Arctic include higher proportions of salmon than previously known and much lower proportions of terrestrial meat than expected. Additionally, plants accounted for $>80 \%$ of the diet of bears that consumed $<20 \%$ salmon. Given that our study focused on July through late September diets of bears to evaluate diet during the time that is most biologically relevant to fat gain, our results are likely seasonally biased as to reflect food resources that are available during the sampling period. Therefore, if salmon were to be used by brown bears, we would expect a higher proportional contribution to be detected when fish are spawning. Similarly, the highest proportion of use for terrestrial meat resources would likely be in spring when vulnerable neonate ungulates and carrion from winter-killed ungulates become available on the landscape (Reynolds and Garner 1987). Although our results reflect July through late September diets, the high amount of salmon and low ( 9\%) amount of terrestrial meat observed in the diets of male and female brown bears raises pertinent questions that should be further evaluated regarding the annual diets of bears in Gates of the Arctic in relation to the management of prey species, habitat use, development, and harvest. Such issues for Gates of the Arctic include evaluating potential impacts of development on foraging habitats, accounting for areas of heightened bear activity in management planning (such as along anadromous waterways), and increased harvest potential with increased access. Additionally, understanding individual differences in foraging behavior within populations is essential for species management and long-term conservation (Fuller and Sievert 2001). As previously suggested (Edwards et al. 2011), identifying variable foraging behaviors within a population can provide a better understanding of complex population dynamics, and ultimately lead to more informed management decisions. Populations of generalist omnivores often consist of specialist individuals (Vander Zanden et al. 2010). 
Therefore, applying a one-size-fits-all approach to generalist populations without acknowledging among-individual variation may ultimately hinder the desired outcome of management actions.

Acknowledgements We thank the National Park Service for funding for this project and the U.S. Geological Survey for their support. We thank Matthew Rogers and the Environment and Natural Resources Institute Stable Isotope Laboratory at the University of Alaska for analyzing hair samples. We thank pilots Troy Cambier, Curtis Cebulski, Jared and Jim Cummings, and Andy Greenblatt for making capture efforts possible and safe. We are grateful to William Leacock and 2 anonymous reviewers for their constructive feedback, which improved this manuscript. Any use of trade, product, or firm names is for descriptive purposes only and does not imply endorsement by the US Government. The findings and conclusions in this article are those of the author(s) and do not necessarily represent the views of the U.S. Fish and Wildlife Service.

\section{Compliance with ethical standards}

Conflict of interest The authors do not have conflicts of interest to declare.

Ethical approval All international, national, and institutional guidelines for the care and use of animals were followed. Institutional Animal Use and Care Committees of the National Park Service (AKR_GAAR_Gustine_GrizzlyBear_2014) and the U.S. Geological Survey, Alaska Science Center (2014-01, 2015-04, 2015-06) approved all capture and handling procedures.

Open Access This article is licensed under a Creative Commons Attribution 4.0 International License, which permits use, sharing, adaptation, distribution and reproduction in any medium or format, as long as you give appropriate credit to the original author(s) and the source, provide a link to the Creative Commons licence, and indicate if changes were made. The images or other third party material in this article are included in the article's Creative Commons licence, unless indicated otherwise in a credit line to the material. If material is not included in the article's Creative Commons licence and your intended use is not permitted by statutory regulation or exceeds the permitted use, you will need to obtain permission directly from the copyright holder. To view a copy of this licence, visit http://creativecommons.org/licenses/by/4.0/.

\section{References}

Araújo MS, Bolnick DI, Layman CA (2011) The ecological causes of individual specialisation. Ecol Lett 14:948-958

Belant JL, Griffith B, Zhang Y, Follmann EH, Adams LG (2010) Population-level resource selection by sympatric brown and American black bears in Alaska. Polar Biol 33:31-40

Ben-David M, Titus K, Beier LR (2004) Consumption of salmon by Alaskan brown bears: a trade-off between nutritional requirements and the risk of infanticide? Oecologia 138:465-474

Bolker BM, Brooks ME, Clark CJ, Geange SW, Poulsen JR, Stevens MHH, White JSS (2009) Generalized linear mixed models: a practical guide for ecology and evolution. Trends Ecol Evol $24: 127-135$
Bolnick DI, Svanback R, Fordyce JA, Yang LH, Davis JM, Hulsey CD, Forister ML (2003) The ecology of individuals: incidence and implications of individual specialization. Am Nat 161:1-28

Bolnick DI, Svanbäck R, Araújo MS, Persson L (2007) Comparative support for the niche variation hypothesis that more generalized populations also are more heterogeneous. Proc Natl Acad Sci 104:10075-10079

Burnham KP, Anderson DR (2002) Model selection and multimodel inference: a practical information-theoretic approach, vol 2. Springer, New York

Carlin BP, Siddhartha C (1995) Bayesian model choice via Markov chain Monte Carlo methods. J Roy Stat Soc B Met 57:473-484

Cattet MR, Caulkett NA, Obbard ME, Stenhouse GB (2002) A body condition index for ursids. Can J Zool 80:1156-1161

Costello CM, Cain SL, Pils S, Frattaroli L, Haroldson MA, van Manen FT (2016) Diet and macronutrient optimization in wild ursids: a comparison of grizzly bears with sympatric and allopatric black bears. PLoS ONE 1:e0153702

Cramer W, Kicklighter DW, Bondeau A, Iii BM, Churkina G, Nemry B, Ruimy A, Schloss AL, The Participants of the Potsdam Npp Model Intercomparison (1999) Comparing global models of terrestrial net primary productivity (NPP): overview and key results. Glob Change Biol 5:1-15

Dormann CF, Elith J, Bacher S, Buchmann C, Carl G, Carré G, Marquéz JRG, Gruber B, Lafourcade B, Leitão PJ, Münkemüller T, McClean C, Osborne PE, Reineking B, Schröder B, Skidmore AK, Zurell D, Lautenbach S (2013) Collinearity: a review of methods to deal with it and a simulation study evaluating their performance. Ecography 36:27-46

Edwards MA, Derocher AE, Hobson KA, Branigan M, Nagy JA (2011) Fast carnivores and slow herbivores: differential foraging strategies among grizzly bears in the Canadian Arctic. Oecologia 165:877-889

Farley SD, Robbins CT (1994) Development of two methods to estimate body composition of bears. Can J Zool 72:220-226

Felicetti LA, Robbins CT, Shipley LA (2003) Dietary protein content alters energy expenditure and composition of the mass gain in grizzly bears (Ursus arctos horribilis). Physiol Biochem Zool 76:256-261

Felicetti LA, Schwartz CC, Rye RO, Gunther KA, Crock JG, Haroldson MA, Waits L, Robbins CT (2004) Use of naturally occurring mercury to determine the importance of cutthroat trout to Yellowstone grizzly bears. Can J Zool 82:493-501

Fuller TK, Sievert PR (2001) Carnivore demography and the consequences of changes in prey availability. In: Gittleman JL, Funk SM, Macdonald D, Wayne RK (eds) Carnivore conservation. Cambridge University Press, Cambridge, pp 163-178

Gasaway WC, Boertje RD, Grangaard DV, Kelleyhouse DG, Stephenson RO, Larsen DG (1992) The role of predation in limiting moose at low densities in Alaska and Yukon and implications for conservation. Wildlife Monogr 120:3-59

Gau RJ, Case R, Penner DF, McLoughlin PD (2002) Feeding patterns of barren-ground grizzly bears in the central Canadian Arctic. Arctic 55:339-344

Gelman A, Rubin DB (1992) Inference from iterative simulation using multiple sequences. Stat Sci 7:457-472

Gordon DM (1991) Behavioral flexibility and the foraging ecology of seed-eating ants. Am Nat 138:379-411

Hechtel JL (1985) Activity and food habits of barren-ground grizzly bears in Arctic Alaska. University of Montana, Thesis

Hilderbrand GV, Farley SD, Robbins CT, Hanley TA, Titus K, Servheen C (1996) Use of stable isotopes to determine diets of living and extinct bears. Can J Zool 74:2080-2088

Hilderbrand GV, Farley SD, Robbins CT (1998) Predicting body condition of bears via two field methods. J Wildl Manage 62:406-409 
Hilderbrand GV, Schwartz CC, Robbins CT, Jacoby ME, Hanley TA, Arthur SM, Servheen C (1999) The importance of meat, particularly salmon, to body size, population productivity, and conservation of North American brown bears. Can J Zool 77:132-138

Hilderbrand GV, Farley SD, Schwartz CC, Robbins CT (2004) Importance of salmon to wildlife: implications for integrated management. Ursus 15:1-10

Hilderbrand GV, Gustine DD, Mangipane B, Joly K, Leacock W, Mangipane L, Erlenbach J, Sorum MS, Cameron MD, Belant JL, Cambier T (2018a) Plasticity in physiological condition of female brown bears across diverse ecosystems. Polar Biol 41:773-780

Hilderbrand GV, Gustine DD, Mangipane BA, Joly K, Leacock W, Mangipane LS, Erlenbach J, Sorum MS, Cameron MD, Belant JL, Cambier T (2018b) Body size and lean mass of brown bears across and within four diverse ecosystems. J Zool 305:53-62

Hilderbrand GV, Gustine DD, Joly K, Mangipane B, Leacock W, Cameron MD, Sorum MS, Mangipane LS, Erlenbach JA (2019) Influence of maternal body size, condition, and age on recruitment of four Alaska brown bear populations. Ursus 29:111-118

Hobson KA, McLellan BN, Woods JG (2000) Using stable carbon $\left(\delta^{13} \mathrm{C}\right)$ and nitrogen $\left(\delta^{15} \mathrm{~N}\right)$ isotopes to infer trophic relationships among black and grizzly bears in the upper Columbia River basin, British Columbia. Can J Zool 78:1332-1339

Hopkins JB III, Ferguson JM (2012) Estimating the diets of animals using stable isotopes and a comprehensive Bayesian mixing model. PLoS ONE 7:e28478

Jacoby ME, Hilderbrand GV, Servheen C, Schwartz CC, Arthur SM, Hanley TA, Robbins CT, Michener R (1999) Trophic relations of brown and black bears in several western North American ecosystems. J Wildl Manag 63:921-929

Johnson SP, Schindler DE (2009) Trophic ecology of Pacific salmon (Oncorhynchus spp.) in the ocean: a synthesis of stable isotope research. Ecol Res 24:855-863

Lafferty DJ, Belant JL, Phillips DL (2015) Testing the niche variation hypothesis with a measure of body condition. Oikos 124:732-740

Lefranc MN, Moss MB, Patnode KA, Sugg WC (1987) Grizzly bear compendium. Interagency Grizzly Bear Committee, Montana

MacHutchon AG, Wellwood DW (2003) Grizzly bear food habits in the northern Yukon, Canada. Ursus 14:225-235

Mangipane LS, Belant JL, Lafferty DJR, Gustine DD, Hiller TL, Colvin ME, Mangipane BA, Hilderbrand GV (2018) Dietary plasticity in a nutrient-rich system does not influence brown bear (Ursus arctos) body condition or denning. Polar Biol 41:763-772

McLellan BN, Hovey FW (1995) The diet of grizzly bears in the Flathead River drainage of southeastern British Columbia. Can J Zool 73:704-712

Moore JW, Semmens BX (2008) Incorporating uncertainty and prior information into stable isotope mixing models. Ecol Lett 11:470-480

Mowat G, Heard DC (2006) Major components of grizzly bear diet across North America. Can J Zool 84:473-489

Noyce KV, Garshelis DL (1994) Body size and blood characteristics as indicators of condition and reproductive performance in black bears. Int C Bear 9:481-496

Oelze VM (2016) Reconstructing temporal variation in great ape and other primate diets: a methodological framework for isotope analyses in hair. Am J Primatol 78:1004-1016

Persson IL, Wikan S, Swenson JE, Mysterud I (2001) The diet of the brown bear Ursus arctos in the Pasvik Valley, northeastern Norway. Wildlife Biol 7:27-37
Phillips DL, Gregg JW (2003) Source partitioning using stable isotopes: coping with too many sources. Oecologia 136:261-269

Plummer M (2013) JAGS Version 3.4. 0 user manual. Available at https ://mcmc-jags.sourceforge.net. Accessed 11 May 2019

Reynolds HV III, Garner GW (1987) Patterns of grizzly bear predation on caribou in northern Alaska. Int C Bear 7:59-67

Robbins CT, Fortin JK, Rode KD, Farley SD, Shipley LA, Felicetti LA (2007) Optimizing protein intake as a foraging strategy to maximize mass gain in an omnivore. Oikos 116:1675-1682

Rode KD, Regehr EV, Douglas DC, Durner G, Derocher AE, Thiemann GW, Budge SM (2014) Variation in the response of an Arctic top predator experiencing habitat loss: feeding and reproductive ecology of two polar bear populations. Glob Change Biol 20:76-88

Rogers MC, Peacock E, Simac K, O’Dell MB, Welker JM (2015) Diet of female polar bears in the southern Beaufort Sea of Alaska: evidence for an emerging alternative foraging strategy in response to environmental change. Polar Biol 38:1035-1047

Servheen C, Herrero S, Peyton B (1999) Bears Status survey and conservation action plan. IUCN, Cambridge

Sorum MS, Joly K, Cameron MD (2019) Use of salmon (Oncorhynchus spp.) by Brown Bears (Ursus arctos) in an Arctic, interior, montane environment. Can Field-Nat 133:151-155

Stock BC, Semmens BX (2013) MixSIAR GUI user manual, version 1.0. Available at https://conserver.iugo-cafe.org/user/brice.semme ns/MixSIAR. Accessed 15 Jan 2019

Svanback R, Bolnick DI (2007) Intraspecific competition drives increased resource use diversity within a natural population. Proc R Soc B Biol Sci 274:839-844

Swenson JE, Adamic M, Huber D, Stokke S (2007) Brown bear body mass and growth in northern and southern Europe. Oecologia 153:37-47

Tans PP, De Jong AFM, Mook WG (1979) Natural atmospheric 14C variation and the Suess effect. Nature 280:826-828

Taylor W, Reynolds H, Ballard W (1989) Immobilization of grizzly bears with tiletamine hydrochloride and zolazepam hydrochloride. J Wildl Manage 53:978-981

Van Valen L (1965) Morphological variation and width of ecological niche. Am Nat 99:377-390

Van Daele LJ, Barnes VG, Belant JL (2012) Ecological flexibility of brown bears on Kodiak Island, Alaska. Ursus 23:21-29

Vander Zanden HB, Bjorndal KA, Reich KJ, Bolten AB (2010) Individual specialists in a generalist population: results from a longterm stable isotope series. Biol Lett 6:711-714

Welch CA, Keay J, Kendall KC, Robbins CT (1997) Constraints on frugivory by bears. Ecology 8:1105-1119

Wilson RR, Gustine DD, Joly K (2014) Evaluating potential effects of an industrial road on winter habitat of caribou in north-central Alaska. Arctic 67:472-482

Zedrosser A, Bellemain E, Taberlet P, Swenson JE (2007) Genetic estimates of annual reproductive success in male brown bears: the effects of body size, age, internal relatedness and population density. J Anim Ecol 76:368-375

Publisher's Note Springer Nature remains neutral with regard to jurisdictional claims in published maps and institutional affiliations. 